\title{
FACTORS AFFECTING LEAN MANAGEMENT ADOPTION IN THREE-STAR HOTELS IN LUXOR AND ASWAN
}

\author{
MICHAEL MAGDY ZAKI \\ FACULTY OF TOURISM \& HOTELS, LUXOR UNIVERSITY \\ SAFWAT M. E. ADAM \\ HOTEL INSTITUTE LUXOR (EGOTH)
}

\section{Abstract}

One of the difficulties that tourism businesses must overcome in the future is how to decrease costs and increase efficiency. That is because the recently fast-growing hotel and tourism industry faces some challenges, particularly economic ones. Thus, this research aims to explore the effect of lean management adoption in three-star hotels category in Luxor and Aswan and to evaluate the awareness level of managers and supervisors of the concept, drivers, and boundaries of the Lean management system. The methodology of the study is a quantitative one with a questionnaire to be a tool for collecting information to test and prove the hypotheses of the study, in order to achieve the study's aims. Moreover, the questionnaire sample was delivered to 130 directors and supervisors of the targeted (13) three-star hotel in Luxor and Aswan, and the results reveal that the majority of the hotels $(86.1 \%)$ adopts the lean management and that there is a statistically strong link between the drivers of lean management and the adopting of it in the three-star hotels in Luxor. Besides, the study shows that the adoption of lean management has led to increasing the flexibility of hotels at $94.4 \%$, and market share at $89 \%$. Moreover, the study has found out that from the key success factors of adopting lean management was management commitment and capability at $88 \%$, and that the absence of quality culture appeared to be the most common and fierce barriers of lean management adoption (93\%). The study manifests that lean management has developed from being a group of tools and techniques to be a philosophy of management.

KEYWORDS: Lean management - Boundaries - Supervisors - Management philosophy.

\section{INTRODUCTION}

Lean Management (LM) is considered a multidisciplinary system of social and technical practices that have to be proceeded and integrated in a consistent way, in order to develop and keep a continuous improvement (CI) culture, although there are some initial increases in operating 
performance due to the adoption of the most popular and well-established lean strategies, the vast majority of lean businesses fail to achieve longterm sustainable results, so most of them eventually return to their traditional business methods (Costa et al., 2019). Knowing the significant effect of the lean approach comes the objective of the present study which is to investigate the role of the human factor in promoting sustainable continuous improvement environment (Bortolotti et al., 2015). Nowadays lean management is broadly applicable in many various fields and is considered one of the most important and common management techniques that are used in administration, healthcare, building, maintenance, business development and much more (Raucha et al., 2016). Although lean management seemed to be applied in the past to the service or tertiary sector that covered the hospitality and tourism area, there are only a few examples of companies in today's literature that have up to now adopted lean management in their organizational processes. What are the reasons behind that? Here comes a need for a study of the application of lean management to this field to identify the most important challenges that might hinder such application.

\section{LITERATURE REVIEW}

\section{THE CONCEPT AND IMPORTANCE}

Over time, there has been an increasing number of continual improvement models based on the notion of increased waste reduction, production line simplification, and quality improvement processes. Some of them are Total Quality Management (TQM), Lean Manufacturing, Six Sigma and Lean Six Sigma (Costa et al., 2014). The lean management model includes a lot of consistent tools and techniques designed to minimize wasteful activity and add value to the product to meet the needs of the customer (Irani, 2011). Lean is a quality management program and philosophy that dictates the time and effort to identify and refine steps of an operation that gives much value to customer, and to remove excessive or inefficient action (Lee et al., 2008).

According to Alsmadi et al. (2012) lean helps to examine business processes and focuses on minimizing unnecessary costs to reduce the waste and to improve inefficient procedures. Then, the importance of the lean management system can be summarized as follows:

1) Identifies problem and bottlenecks

2) To increase the outputs of businesses

3) To ensure that staff time is best used value-adding activities.

4) Save money - reduce overhead in paperwork 
5) Simplify processes

6) Conform to rules \& regulations and codes of conduct

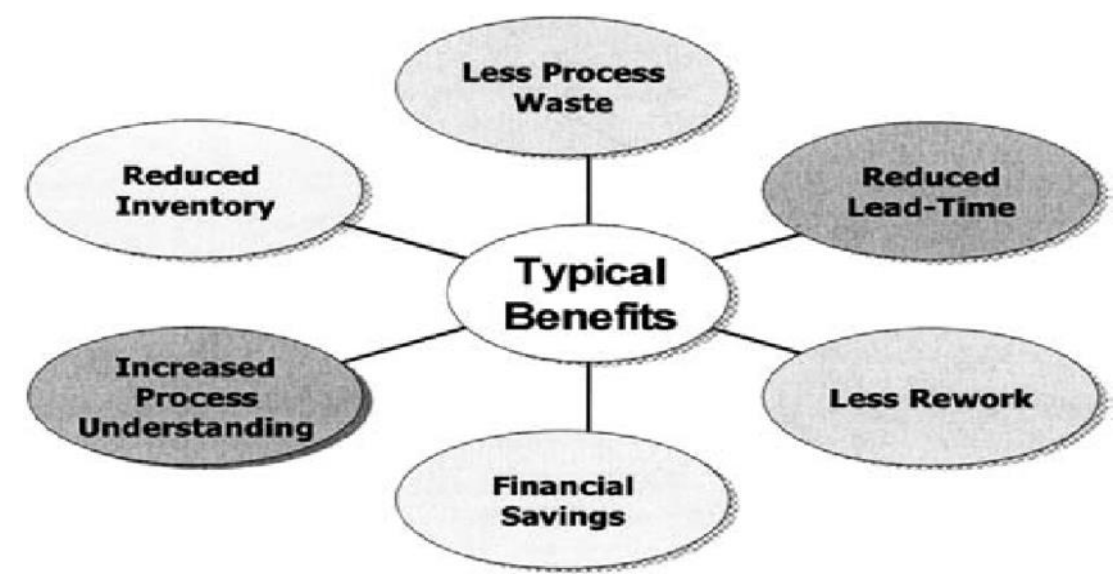

Figure 1: The benefits of lean

Source: Melton (2005)

\section{PRINCIPLES OF LEAN MANAGEMENT}

Lean Principles and Practices are to create value for the customer with growth for every type of organization where it is implemented (Simon and Canacari, 2012). According to Cardiff University (2015), the primary principles of lean management can be defined in different ways. The book "Lean Thinking" is referred to be one of the most pervasive approaches. Womack and Jones (2003) as well as Rother and Shook (2003) divided the lean management's philosophy into five principles:

1) Specify a value from the customer's point of view.

2) Manifest and map the value stream: classify all the value stream steps for each product family that eliminate non-value-creating steps.

3) Create a flow to ensure that the value-creating steps take place in a tight sequence so that products flow smoothly to the customer.

4) Customer pull response: Allow customers to pull value from the next upstream operation once the flow is implemented.

5) Seek excellence 


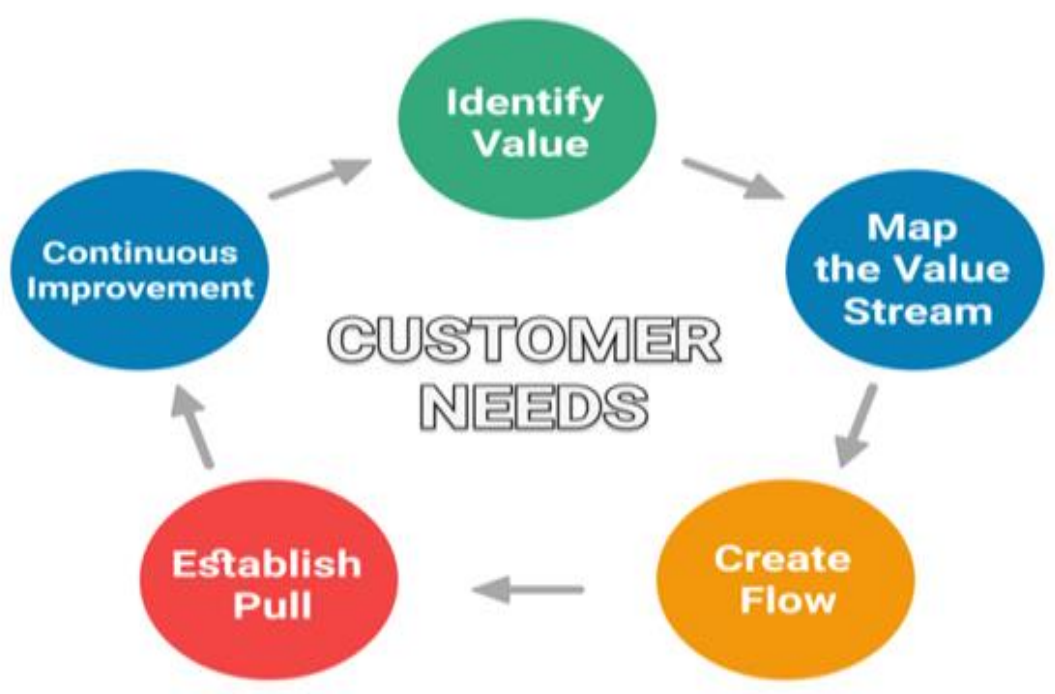

Figure 2: Principles of Lean Management

Source: Rother and Shook (2003)

THE FACTORS INFLUENCING ADOPTING LEAN MANAGEMENT (POSITIVE AND NEGATIVE)

MOTIVATIONS FOR ADOPTING LEAN MANAGEMENT (POSITIVE FACTORS)

According to McMahon (2014) and De Koeijer et al. (2014), the key drivers needed for a lean business, as most researcherss have pointed out, are summarized in the following list:

- To increase market share

- To increase efficiency

- To remove internal restrictions

- Developing a performance indicator

- Need to use best practices in the world

- Part of the organization's progressive program

- Customer requirement/ Customer motivation

- Mother company requirement

Lean is a system which significantly reduces the time spent between an order of a customer and shipping the goods by reducing all types of waste such as glitches, manufacturing mess, inventory issues, unnecessary activities, consumer annoyance, expense, cycle problems, and process confusion as reported by (Melton, 2005). 


\section{KEY SUCCESS FACTORS}

According to Phogat (2013) and Jituri et al. (2018), the factors of the successful implementation of Lean are summarized as follow:

- Organizational culture and possession

- To develop institutional preparation

- Management duty and capacity

- Providing satisfactory assets to help change

- External support from experts

- Effective correspondence and collaboration

- A key way to improvement

- Teamwork and shared entire frameworks' thinking

- Setting practical time-bound plans and the best use responsibilities for change

\section{BARRIERS OF ADOPTING LEAN MANAGEMENT (NEGATIVE FACTORS)}

The main obstacle that hinders the adoption of lean in hospitality is that it necessitates a change in culture, and requires a new mentality. Another significant obstruction is that the commitment and investment required to implement as expenses of time and money are difficult for some management to overcome, for even in a little property or organization, implementation can happen in a year or more (Lancaster, 2011). Moreover, the extra cost of training new employees on lean and six sigma principles can probably be an undesirable burden for leadership (Kumar et al., 2009). Jituri et al. (2018) outline the boundaries of lean management in some similar points such as confusing the term and the aim of lean, having no resources (time-expertise, financing), cultural specificity, absence of interactive communication, having no interest, commitment to lean, not even knowing what the lean management means, and finally the lack of adequate training. Besides, Pande et al. (2002) explain that the implementation problems they find are that senior management still fails to know about lean, most managers do not understand the needs of customers and use guessing when determining where to need change. Besides, both managers and thinking that lean is a quick fix, are other challenges. 


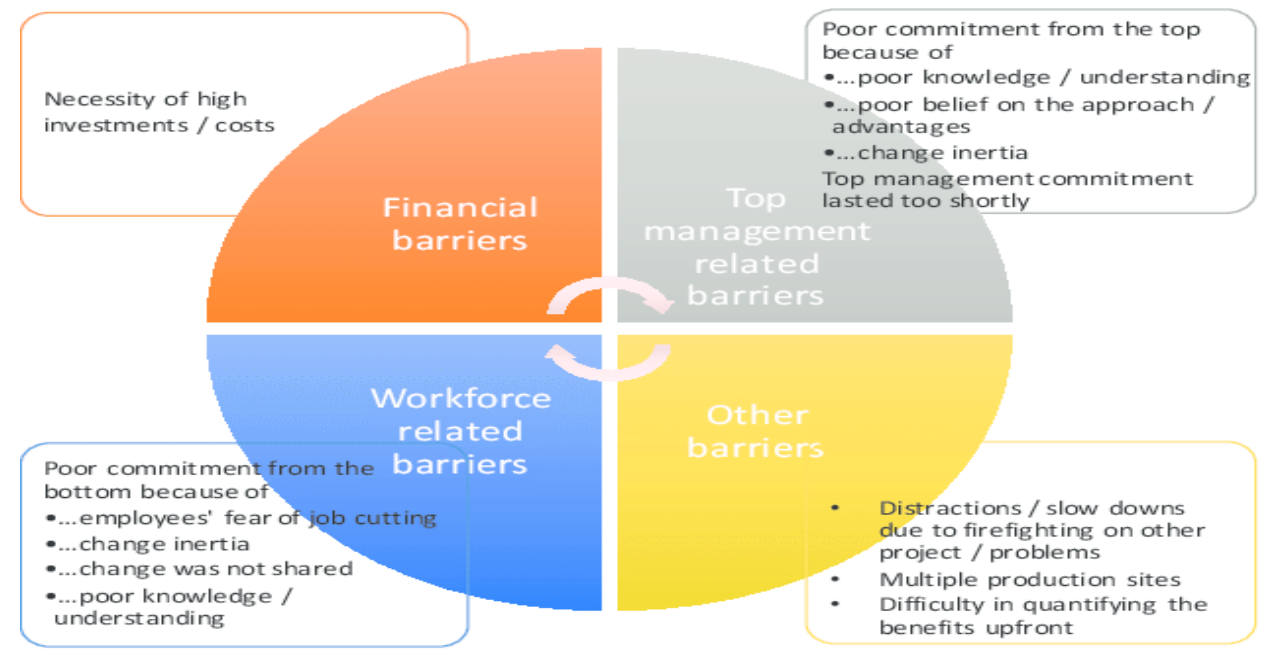

Figure 3:Barriers of lean management Source: Leite, (2015)

\section{EXAMPLES Of LEAN MANAGEMENT IN THE HOSPITALITY INDUSTRY}

\section{YUKAI RESORT - JAPAN}

All resort responsibilities are performed by all staff in the Yukai resort. According to Raucha et al. (2016), this minimizes staff and reduces overall costs. Still, this ensures high quality, dinner and breakfast are buffet style, which decreases the staff needs; besides, personnel are involved in lean management, the director leads Kaizen circles every week and month, the receptionists, in their free time go to assist in other areas, maybe the kitchen or the laundry.

\section{APEX Hotels In THE UNITED KINGDOM}

One of the largest monthly costs at Apex hotels is the laundry. The lean group has mapped out the end-to-end cycle making the process of the laundry be daily to reduce the non-value-adding activities of the process. The lean team was able to save about 5,728 man-hours per year by removing these activities and reforming procedures, organizational structures, and workplace preparation. In fact, applying lean has not only saved much money, but also the guest service and the staff working conditions have been significantly improved (Raucha et al, 2016).

\section{STARWOOD HoTELS}

The lean of Starwood Hotels was implemented in 2001. Consequently, the firm earned quick profits. Incremental revenues grew by $19 \%$ and overall customer spending grew by approximately $12 \%$ in the months following 
implementation. By centralizing the spa booking group using lean Starwood tools, increases rose from 91 million pounds to 141 million pounds. Moreover, the production of food has been competitive on a caseby-case basis because of its similarity with the manufacturing sector (Pearlman and Chacko, 2012)

\section{STATEMENT OF THE PROBLEM}

Adopting lean management in hospitality had limitations, in spite of the Starwood Hotels' recorded progress in adopting it. Lean's lack of implementation and reluctance is due to the disincentive task of changing the organization's culture and the resource costs related to training and infrastructure building (Pearlman and Chacko, 2012)

\section{RESEARCH OBJECTIVES}

The following objectives must be fulfilled, to achieve the research objectives:

- Identifying the affecting factor on lean management Adoption in threestar hotels in Luxor

- Identifying how far managers and supervisors know about the lean management concept and its drivers

- Determining boundaries that face Luxor hotels in adopting lean

\section{RESEARCH HYPOTHESIS}

1.A statistically strong connection between the drivers of lean management and the adopting of lean management is not found in the three-star hotels in Luxor.

2. A statistically strong connection between the boundaries of lean

Management and lean management adoption is not found in the three-star hotels in Luxor.

\section{METHODOLOGY}

A quantitative method has been adopted by the present study using the questionnaire as a data collection tool to test the hypotheses of the study and achieve its goals. The approach for the current study was motivated by the findings of the primary study and the aims of the subsequent analysis. The study focuses on exploring the affecting factor of lean management adoption in the three-star hotels in Luxor and Aswan and focuses on evaluating the awareness levels of managers and supervisors about the concept, drivers, and boundaries of lean management; the researchers sees that the quantitative method is a suitable method for giving this study a practical significance. Thus, the present study has adopted the quantitative 
method that has included a combination of adapted and developed questionnaires.

\section{Population AND SAMPling}

The study's target has been the three-star hotels in Luxor and Aswan cities counted (13) hotels that are mentioned in detail below the table (1) as per the information from the website of the Egyptian Hotel Association.

Table 1: Luxor and Aswan three-star hotels

\begin{tabular}{|c|c|}
\hline \hline SR & Hotel Name \\
\hline \hline 1 & El Gezira Gardens Hotel \\
\hline \hline 2 & Edris total Hotel \\
\hline \hline 3 & Emilio hotel \\
\hline \hline 4 & Morris Hotel \\
\hline \hline 5 & New Pola hotel \\
\hline \hline 6 & Philippe Hotel \\
\hline \hline 7 & Queen Valley Hotel \\
\hline \hline 8 & Royal House Hotel \\
\hline \hline 9 & St Joseph Hotel \\
\hline \hline 10 & Susana Hotel \\
\hline \hline & Aswan Hotels \\
\hline \hline 1 & Cleopatra Hotel \\
\hline \hline 2 & Isis hotel \\
\hline \hline 3 & Marhaba Palace Hotel \\
\hline
\end{tabular}

Cited in: (Egyptian Hotel Association 2016)

The cause of selecting this category is that most of the three-star hotels that apply lean management programs and those hotels are locally managed. A purposeful sampling technique (also referred to as convenience sampling) has been used in this analysis to select hotel managers and hotel supervisors listed in table (1), and the researchers select five departments in the listed hotels in table (1), i.e., top management department, the department of finance, the department of room division (front office and housekeeping), the department of food \& beverages and the department of sales \& marketing. The researchers thereafter select a manager and supervisors from each department to be the department manager and supervisors, as the purposeful study sample. 


\section{The Tool Of Data Collection}

The present study has been carried out as a total survey study, which in the social sciences is the most common (quantitative) study design. Survey designs are very flexible, so they can appear in many forms, but all of them are characterized by data collection using the questionnaire forms whether by telephone or face-to-face, by postal services or increasingly using web and email forms (Muijs, 2010). For collecting data from the targeted sample, the researchers use a hard copy form of a questionnaire (130), a form that has been distrusted. Books, articles in academic journals, government statistics, web data, and publications of other forms are the popular forms of secondary resources. In the "Review of Literature" mentioned above, all secondary resources have been clarified.

\section{RELIABILITY AND VALIDITY}

For 13 managers in Luxor and Aswan hotels, the questionnaire was primarily pre-tested for validity. The researchers used the test of personal comparison to assess the internal consistency of all claims and to assert that the analysis was accurate. Furthermore, the questionnaire was sent to professors in the study department of the hotels to receive feedback on the clearance of the instructions and the questions' accuracy. Comments and feedback from the pre-test have been used to update the questionnaire's directions and designs. Table (2) results show that there is a positive clear relationship between questionnaire statements at 0.01 degree, with 0.81 for the dimensions of the questionnaire.

\section{Table 2: Internal coherence of the questionnaire under investigation}

\begin{tabular}{|l|c|c|}
\hline \multicolumn{1}{|c|}{ Dimension } & Corr. & P. Value \\
\hline The concept of lean management & 0.80 & 0.000 \\
\hline Lean management Adoption & 0.85 & 0.000 \\
\hline The driver of lean Management & 0.83 & 0.000 \\
\hline Key success factors & 0.83 & 0.000 \\
\hline Boundaries of adoption lean management & 0.84 & 0.000 \\
\hline Total & 0.81 & 0.000 \\
\hline
\end{tabular}

Measuring reliability for all scales necessitated the calculation of Cronbach Alpha to determine the internal consistency of the scale. Cronbach alpha's calculation is based on the items' number on the questionnaire and the ratio between the averages of both inter-item covariance and item variance. In most circumstances of sociological research, the reliability factor of 0.50 or higher is considered appropriate. The reliability of the Cronbach Alpha was measured and the tests clarified that the coefficients of reliability for 
all instruments exceeded 0.80 , indicating that the system is accurate for use. For the present study, Cronbach alpha is described as follows in Table (3) for all variables survey instruments:

Table 3: Reliability measurement

\begin{tabular}{|l|c|c|}
\hline \multicolumn{1}{|c|}{ Dimension } & $\begin{array}{c}\text { Statements } \\
\text { Number }\end{array}$ & Alpha Cronbach's \\
\hline The concept of lean management & 4 & 0.82 \\
\hline Lean management Adoption & 2 & 0.86 \\
\hline The driver of lean Management & 9 & 0.85 \\
\hline Key success factors & 9 & 0.82 \\
\hline $\begin{array}{l}\text { Boundaries of adoption lean } \\
\text { management }\end{array}$ & 15 & 0.83 \\
\hline
\end{tabular}

The above table shows that it is greater than or equal to 0.80 for Alpha Cronbach. This indicates that the internal harmony between each section of the questionnaire and other sections is very reasonable in the questionnaire. Thus, the researchers assert that all statements in the questionnaire are reliable and appropriate for analysis (Hair, 2014).

\section{RESUlTS AND DISCUSSION}

\section{The Questionnaire (PART ONE): Lean MANagement ConCEPT}

In this part, the questions have been intended to evaluate the level of understanding of the lean management concept. Table (4) shows the answer.

\section{Table (4) the concept of lean management}

\begin{tabular}{|l|c|c|c|}
\hline \multicolumn{1}{|c|}{ Items } & F & P & R \\
\hline $\begin{array}{lll}\text { Active exchange of information on quality among all } \\
\text { stakeholders }\end{array}$ & 5 & 3.85 & 4 \\
\hline $\begin{array}{l}\text { Policy development and appropriate alternatives to } \\
\text { address business problems }\end{array}$ & 8 & 6.15 & 3 \\
\hline $\begin{array}{l}\text { Lean's A quality management program and } \\
\text { philosophy focusing time and efforts on identifying } \\
\text { and improving steps in a customer's valuable } \\
\text { operation and removing wasteful or unnecessary } \\
\text { process steps }\end{array}$ & 104 & 80 & 1 \\
\hline Lean is a management strategy to reduce work stress & 13 & 10 & 2 \\
\hline
\end{tabular}

As noticed in the above table, the concept varies among the respondents and each group of the respondent indicated the meaning of lean 
management according to his own knowledge, and depending on his work experience. Respondents' definitions are categorized respectively according to the most chosen concept as follow:

Lean's a quality management program and philosophy focusing time and efforts on identifying and improving steps in a customer's valuable operation and removing wasteful or unnecessary process steps $(80 \%)$

Lean is a management strategy to reduce work stress (10\%)

Policy development and appropriate alternatives to address business problems (6.15) Active exchange of information on quality among all stakeholders $(3.85 \%)$ The previous results indicated that the majority $(80 \%)$ of the respondent had a high level of understanding of the lean management concept and this result agrees with (Costa et al., 2014 and Lee et al., 2008)

Table (5) Lean management Adoption

\begin{tabular}{|c|c|c|}
\hline Answer & F & P\% \\
\hline Yes & 112 & 86.1 \\
\hline No & 18 & 13.8 \\
\hline Total & 130 & 100 \\
\hline
\end{tabular}

According to Table (5) almost of hotels field of study (86.1) are Adopting lean management. 
Table (6) Drives of adoption lean management (positive factors)

\begin{tabular}{|c|c|c|c|c|c|c|c|c|c|}
\hline Items & $\begin{array}{c}\text { Strongly } \\
\text { Agree }\end{array}$ & Agree & Neutral & Disagree & $\begin{array}{c}\text { Strongly } \\
\text { disagree }\end{array}$ & Mean & S.D. & P & R \\
\hline To increase flexibility & 93 & 37 & 0 & 0 & 0 & 4.72 & 0.45 & 94.4 & 1 \\
\hline To increase market share & 67 & 54 & 9 & 0 & 0 & 4.45 & 0.62 & 89 & 2 \\
\hline $\begin{array}{c}\text { The need for survival } \\
\text { from internal constraints }\end{array}$ & 54 & 58 & 18 & 0 & 0 & 4.28 & 0.69 & 85.6 & 5 \\
\hline $\begin{array}{c}\text { Development of key } \\
\text { performance indicator }\end{array}$ & 56 & 37 & 37 & 0 & 0 & 4.15 & 0.83 & 83 & 7 \\
\hline $\begin{array}{c}\text { Desire to employ world } \\
\text { best practice }\end{array}$ & 46 & 57 & 0 & 9 & 0 & 4.25 & 0.82 & 85 & 6 \\
\hline $\begin{array}{c}\text { Part of the organization's } \\
\text { continuous programmer }\end{array}$ & 46 & 84 & 0 & 0 & 0 & 4.35 & 0.48 & 87 & 4 \\
\hline $\begin{array}{c}\text { Drive to focus on } \\
\text { customers }\end{array}$ & 65 & 56 & 9 & 0 & 0 & 4.43 & 0.62 & 88.6 & 3 \\
\hline $\begin{array}{c}\text { Requirement/Motivation } \\
\text { by customers }\end{array}$ & 28 & 28 & 47 & 27 & 0 & 3.44 & 1.05 & 68.8 & 9 \\
\hline $\begin{array}{c}\text { The requirement by the } \\
\text { mother company }\end{array}$ & 28 & 10 & 92 & 0 & 0 & 3.51 & 0.83 & 70.2 & 8 \\
\hline \begin{tabular}{c} 
Total \\
\hline
\end{tabular} & 483 & 421 & 212 & 36 & 0 & 4.17 & 0.84 & 83.4 & \\
\hline
\end{tabular}


The key factors supporting lean adoption in hotels have been defined in the literature review. The questionnaires measured the quality of each of these operators. The respondents were asked to choose from the table identified driver list (6). As noticed in the above table, most of the respondents (93) strongly agree that the driver of adoption lean management has increased flexibility at (94.4\%.) mean (4.72). According to the table (6), the majority of the respondents (67) strongly agree that the adoption of lean management increases the market share (89\%) mean (4.45). According to the respondent views in the table almost (58) of them, they agree that the adoption of lean management need for survival from internal constraints $(85.6 \%)$ mean (4.28). The respondent strongly agrees that the adoption of lean management leads to the development of key performance indicator (83\%) mean (4.15). The adoption of lean management in three-star hotels has led to increases desire to employ the world best practice $(85 \%)$ mean (4.25).Most of the respondents (84) agree that the driver of adoption lean management is a part of the organization's continuous programmer $(87 \%)$ means (4.35).The majority of the respondents (65) strongly agree that the lean management adoption drive focuses on customers $(88.6 \%)$ mean (4.45).According to the table, most of the respondents (47) are neutral that the adoption of lean management requirement/Motivation by customers (68.1) means (3.44).According to the table, most of the respondents (92) are neutral that the adoption of lean management requirement by mother company (70) means (4.17). Table (6) results show that the managers and supervisors who agreed with the statements dimension drives of adoption lean management with an average mean (4.17) and with an average percentage (83.45). Furthermore, these results agree with that mentioned by McMahon (2014) and De Koeijer et al. (2015). 
Table (7) Key success factors of adoption lean management

\begin{tabular}{|c|c|c|c|c|c|c|c|c|c|}
\hline Items & $\begin{array}{l}\text { Strongly } \\
\text { Agree }\end{array}$ & Agree & Neutral & Disagree & $\begin{array}{l}\text { Strongly } \\
\text { disagree }\end{array}$ & Mean & S.D. & $\mathbf{P}$ & $\mathbf{R}$ \\
\hline Organizational culture and ownership & 27 & 73 & 20 & 10 & 0 & 3.9 & 0.81 & 78 & 7 \\
\hline Developing organizational readiness & 46 & 75 & 9 & 0 & 0 & 4.28 & 0.58 & 85.6 & 2 \\
\hline $\begin{array}{l}\text { Management commitment and } \\
\text { capability }\end{array}$ & 84 & 19 & 27 & 0 & 0 & 4.44 & 0.81 & 88.8 & 1 \\
\hline $\begin{array}{l}\text { Providing sufficient resources to help } \\
\text { change }\end{array}$ & 47 & 47 & 27 & 9 & 0 & 4.02 & 0.92 & 80.4 & 5 \\
\hline $\begin{array}{l}\text { First of all, external support from } \\
\text { experts }\end{array}$ & 29 & 47 & 27 & 27 & 0 & 3.6 & 1.05 & 72 & 9 \\
\hline $\begin{array}{l}\text { Effective communication and } \\
\text { engagement }\end{array}$ & 45 & 66 & 19 & 0 & 0 & 4.2 & 0.67 & 84 & 4 \\
\hline A strategic approach to improvements & 37 & 56 & 28 & 9 & 0 & 3.93 & 0.88 & 78.6 & 6 \\
\hline $\begin{array}{l}\text { Teamwork and the integration of } \\
\text { entire systems thinking }\end{array}$ & 38 & 83 & 9 & 0 & 0 & 4.22 & 0.56 & 84.4 & 3 \\
\hline $\begin{array}{l}\text { Timing for setting practical time- } \\
\text { bound for change and making the } \\
\text { best use of duties and enthusiasm for } \\
\text { change }\end{array}$ & 38 & 29 & 54 & 9 & 0 & 3.74 & 0.96 & 74.8 & 8 \\
\hline Total & 391 & 495 & 220 & 64 & 0 & 4.04 & 0.86 & 80.8 & \\
\hline
\end{tabular}


The results in Table (7) show that the respondents have agreed on only five statements of Key success factors of adoption lean management, that according to their means are arranged as follow:

The statement of "management commitment and capability" has the highest percentage of the respondents' agreement at (Mean=4.44).

The "developing organizational readiness" is considered a very important key success of adoption lean management at percentage $85.6 \%$ and (mean 4.28) The statement of "teamwork and the integration of entire systems thinking" has the respondents' agreement at $(M e a n=4.22)$. Moreover, the respondents agree with this statement at the percentage (84. 4\%).According to the respondents' view in the above table, the effective communication and engagement are factors of the success of adoption lean in management at (mean 4.2) and at the percentage (84\%).The statement of providing adequate resources to support change leads to the success of the adoption of lean management at (mean 4.02) and of percentage (80.45\%). The respondents agree with the statement of the strategic approach to improvements as a key success of lean management adoption at (mean 3.93 ) and of percentage (78.6\%). Organizational culture and ownership is lead to the success of lean management adoption in three-star hotels at (mean 3.9) and of a percentage (78\%).The statement of "timing for setting practical time-bound for change and making the best use of duties and enthusiasm for change" has got a respondents' agreement at (mean 3.74), and at the percentage (74.8\%)."First of all, external support from experts" has got the lowest agreement of the respondent at (mean 3.74). Moreover, the respondents agree with this statement with a percentage (72\%). Table (7) results show that the managers and supervisors who have agreed on the statements of dimension, the Key success factors of adoption lean management, with average mean 4.04 and average percentage $80.8 \%$, and this agrees with what was mentioned by Phogat (2013) and Jituri et al. (2018). 
Table (8) Boundaries of adoption lean management (negative factors)

\begin{tabular}{|c|c|c|c|c|c|c|c|c|c|c|}
\hline \multicolumn{2}{|r|}{ Items } & $\begin{array}{c}\text { Strongly } \\
\text { Agree }\end{array}$ & Agree & Neutral & Disagree & $\begin{array}{l}\text { Strongly } \\
\text { disagree }\end{array}$ & Mean & S.D. & $\mathbf{P}$ & $\mathbf{R}$ \\
\hline \multirow{4}{*}{$\begin{array}{c}\text { Financial } \\
\text { Boundaries }\end{array}$} & $\begin{array}{l}\text { Lack of inancial } \\
\text { resource } \\
\text { vailability }\end{array}$ & 46 & 20 & 45 & 19 & 0 & 3.72 & 1.1 & 74.4 & 1 \\
\hline & $\begin{array}{l}\text { The necessity of } \\
\text { high investment }\end{array}$ & 10 & 47 & 28 & 45 & 0 & 3.17 & 0.99 & 63.4 & 3 \\
\hline & $\begin{array}{l}\text { The necessity of } \\
\text { high cost }\end{array}$ & 10 & 47 & 27 & 46 & 0 & 3.16 & 1 & 63.2 & 4 \\
\hline & $\begin{array}{l}\text { Extra cost to rain } \\
\text { new employees }\end{array}$ & 10 & 47 & 64 & 9 & 0 & 3.45 & 0.73 & 69 & 2 \\
\hline \multirow{4}{*}{$\begin{array}{c}\text { Top } \\
\text { management } \\
\text { Boundaries }\end{array}$} & $\begin{array}{l}\text { Poor knowledge } \\
\text { and nderstanding }\end{array}$ & 84 & 37 & 9 & 0 & 0 & 4.58 & 0.62 & 91.6 & 2 \\
\hline & $\begin{array}{l}\text { Poor } \\
\text { commitment } \\
\text { from top } \\
\text { management }\end{array}$ & 66 & 37 & 27 & 0 & 0 & 4.3 & 0.79 & 86 & 3 \\
\hline & $\begin{array}{l}\text { Absence of } \\
\text { quality culture }\end{array}$ & 84 & 46 & 0 & 0 & 0 & 4.65 & 0.48 & 93 & 1 \\
\hline & $\begin{array}{l}\text { Resistance to } \\
\text { change }\end{array}$ & 37 & 66 & 27 & 0 & 0 & 4.08 & 0.7 & 81.6 & 4 \\
\hline
\end{tabular}


International Journal of Tourism and Hospitality Management Volume 2, Issue 2, December 2019

\begin{tabular}{|c|c|c|c|c|c|c|c|c|c|c|}
\hline & $\begin{array}{l}\text { Absence of clear } \\
\text { communication }\end{array}$ & 37 & 38 & 55 & 0 & 0 & 3.86 & 0.83 & 77.2 & 5 \\
\hline \multirow{6}{*}{$\begin{array}{l}\text { Workforce } \\
\text { and } \\
\text { Boundaries }\end{array}$} & $\begin{array}{l}\text { Requiring a } \\
\text { change in culture, } \\
\text { and demanding a } \\
\text { new way of } \\
\text { thinking }\end{array}$ & 46 & 75 & 9 & 0 & 0 & 4.28 & 0.58 & 85.6 & 3 \\
\hline & $\begin{array}{l}\text { Poor commitment } \\
\text { from employees }\end{array}$ & 47 & 74 & 9 & 0 & 0 & 4.29 & 0.59 & 85.8 & 2 \\
\hline & $\begin{array}{l}\text { Poor knowledge } \\
\text { and understanding }\end{array}$ & 75 & 55 & 0 & 0 & 0 & 4.58 & 0.49 & 91.6 & 1 \\
\hline & $\begin{array}{l}\text { Employees fear of } \\
\text { job cutting }\end{array}$ & 47 & 46 & 37 & 0 & 0 & 4.08 & 0.8 & 81.6 & 4 \\
\hline & Lack of experience & 56 & 29 & 27 & 18 & 0 & 3.95 & 1.09 & 79 & 6 \\
\hline & $\begin{array}{l}\text { a small property } \\
\text { can take a longer }\end{array}$ & 56 & 37 & 27 & 10 & 0 & 4.07 & 0.97 & 81.4 & 5 \\
\hline Total & & 711 & 701 & 391 & 147 & 0 & 4.01 & 0.93 & 80.2 & \\
\hline
\end{tabular}


The boundaries recognized in the review of literature have been assessed. Some statements have been posed, and the respondents have been asked to show whether they agreed or disagreed on a Likert scale. According to the results in Table (8), the respondents agree on almost of the dimension's statements of boundaries of adoption lean management in three-star hotels in Luxor and Aswan, which according to their means are put in the following order:

The top management boundaries statements have got the highest agreement and percentage from the respondent as shown in Table (8).

The statement of the absence of quality culture has the highest agreement (mean 4.65) and percentage (93\%). The statement of poor knowledge and understanding has got (mean 4.58) and percentage (4.58) and percentage (91\%).Poor commitment from top management is one of the boundaries from the point of respondent views at (mean 4.3) moreover at the percentage (86\%). The statement of resistance to change has got agreement from the respondent at (mean 4.08) and besides at the percentage (81.6\%).

The absence of clear communication is one of the boundaries of lean management adoption, as indicated in the table, which has got a (mean 3.86) and percentage at (77. 2\%).The results in Table (8) show that the respondents have agreed with all statements of dimension workforce and boundaries, which according to their means are put in the following order: According to the respondent views, the poor knowledge and understanding of employees are the major boundaries in this dimension at (mean 4.58 and percentage 91.6\%). The statement of poor commitment from employees is one of the important challenges for the adoption of lean management, as mentioned in literature review, and the respondents agree with this at (mean 4.29, percentage 85.8\%).The statement of requiring a change in culture and demanding a new way of thinking has got the agreement of the respondents at (mean 4.28) and highest percentage at $(85.6 \%)$.The statement of employees' fears of job cutting, according to the respondents' answers, is considered one of the boundaries at (mean 4.08 and $81.4 \%$ ). The statement of a small property can take longer for adaption lean management has the agreement of the respondents at (mean 4.07 and percentage at 81.4). According to the respondents' views, the lack of experience represents the lowest boundaries in this dimension at (mean 3.95 and percentage 79\%). The results in Table (8) show that the respondents have agreed with all statements of dimension financial boundaries, which according to their means are put in the following order: The respondents agree with the statement of Lack of Financial resource availability as a boundary of lean management adoption at (mean 3.74 and percentage $74.4 \%$ ). The statement of extra cost to train new employees has got agreement from the respondent as boundaries for lean management 
adoption at (mean 3.45 and 69\%).According to the respondents' views in the above table, they agree with the statement of the necessity of high investment at (mean 3.17 and percentage at 63.4\%). The lowest statement in this type of boundaries, as shown in the above table, shows that the necessity of high cost is agreed on by the respondents at (mean 3.16 and $63.2 \%$ ). Results of Table (8) clarify that the managers and supervisor have agreed with statements of dimension boundaries of adoption lean management with average mean 4.01 and average percentage $80.2 \%$, and this agrees with what was mentioned by Kumar et al. (2009) and Lancaster (2011) as well as Leite (2015).

\section{STUDY HYPOTHESES TESTING}

In this section, the researchers attempt to investigate and analyze the relations between independent and dependent variables H1. No statistically significant relationship is found between the drivers of lean management and the adopting of lean management in three-star hotels in Luxor.

Table (9) relationship between the drivers of lean management and the adopting of lean management

\begin{tabular}{|c|c|c|c|c|c|}
\hline \multicolumn{6}{|c|}{ ANOVA } \\
\hline & $\begin{array}{l}\text { Sum of } \\
\text { Squares }\end{array}$ & Df & $\begin{array}{c}\text { Mean } \\
\text { Square }\end{array}$ & $\mathbf{F}$ & Sig. \\
\hline $\begin{array}{l}\text { Among } \\
\text { Groups }\end{array}$ & 16.635 & 1 & 16.635 & \multirow{3}{*}{31.186} & \multirow{3}{*}{0.000} \\
\hline $\begin{array}{l}\text { Within } \\
\text { Groups }\end{array}$ & 1850.357 & 128 & 14.456 & & \\
\hline Total & 1866.992 & 129 & & & \\
\hline
\end{tabular}

Table (9) puts a conclusion that there is a significant level of ANOVA at (129), and F (31.186). This means that the first hypothesis of the study is incorrect and that the alternative hypothesis is accepted. Besides, a statistically relationship can be found between the drivers of lean management and the adopting of lean management in three-star hotels in Luxor.H2. No statistically relationship can be found between the boundaries of lean management and the adopting of lean management in three-star hotels in Luxor. 
Table (10) relationship between the boundaries of lean management and the adopting of lean management in three-star hotels in Luxor

\begin{tabular}{|l|c|c|c|c|c|}
\hline \multicolumn{7}{|c|}{ ANOVA } \\
\hline & $\begin{array}{c}\text { Sum of } \\
\text { Squares }\end{array}$ & Df & $\begin{array}{c}\text { Mean } \\
\text { Square }\end{array}$ & F & Sig. \\
\hline \begin{tabular}{l|c|c|c|c|} 
Among \\
Groups
\end{tabular} & 275.420 & 1 & 275.420 & & \\
\hline $\begin{array}{l}\text { Within } \\
\text { Groups }\end{array}$ & 5127.357 & 128 & 40.057 & 1.151 & .010 \\
\hline Total & 5402.777 & 129 & & & \\
\hline
\end{tabular}

It is clear from the previous table (10) that no statistically significant relationship can be found between the boundaries of lean management and the adopting of lean management in three-star hotels in Luxor where the value of $(\mathrm{P}) 1.151$ is not statistically significant; and this confirms the validity of the second hypothesis of the study.

\section{RECOMMENDATIONS}

Based on the literature review and the field study results, recommendations can be divided into the following two items:

\section{GENERAL MANAGERS AND SUPERVISOR IN THREE-STAR HOTELS:}

1.Increasing the awareness level of hotel workers about the quality culture and its advantages.

2.Hotels' general managers and supervisor should have considered lean management as a philosophical administrative approach.

3.The personnel in three-star hotels in Luxor and Aswan have had a positive attitude toward lean management. Yet, the knowledge, preparation, and participation of that personnel who work directly at the location where the control activities take place were found to be insufficient. The management of three-star hotels must know the importance of lean management and the role in increasing the market share and reducing the cost and time.

4.A supposition to train the hotel staff on work achievement under lean management.

5.Setting up a control system that contributes to waste management and reduces lean management problems. 


\section{RECOMMENDATIONS TO THE MINISTRY OF TOURISM:}

1.Developing training programs by the Egyptian hotels federation for all hotels and special three-star hotels to spread awareness and raise the efficiency of workers and increasing the knowledge of them about the role and importance of quality and lean management.

2.The Ministry of Tourism should recommend the hotels that lean can be applied to their services and can have a huge impact on the results of the project by removing waste and streamlining processes.

\section{CONCLUSION}

This analysis of applied research indicates that Lean can be applied to hotel operations and can have a huge impact on the results of the work. The hotel under review was able to increase the time available by removing waste and streamlining processes using the Lean approach. Thus, Lean Management has been used to improve the productivity of hotel operations. Many Hotels worldwide had implemented lean management and achieved great improvements.

\section{REFERENCES}

Alsmadi, M., Almani, A., \& Jerisat, R. (2012). A comparative analysis of Lean practices and performance in the UK manufacturing and service sector firms. Total Quality Management \& Business Excellence, 23(3-4), 381-396.

Cardiff University. http://www.cardiff.ac.uk/lean/principles/. Last update 25.05.2019.

Costa, F., Lispi, L., Staudacher, A. P., Rossini, M., Kundu, K., \& Cifone, F. D. (2019). How to foster Sustainable Continuous Improvement: A cause-effect relations map of Lean soft practices. Operations Research Perspectives, 6, 100091.

Costa, S. E., Lima, E. P., \& Garbuio, P. A. (2014). Lean, Six Sigma and Lean Six Sigma: an analysis based on operations strategy. International Journal of Production Research 52(3), 804-824.

De Koeijer, R. J., Paauwe, J., \& Huijsman, R. (2014). Toward a conceptual framework for exploring multilevel relationships between Lean Management and Six Sigma, enabling HRM, strategic climate and outcomes in healthcare. The International Journal of Human Resource Management, 25(21), 2911-2925.

EHA (Egyptian Hotel Association). (2016). The Egyptian Hotel Guide. ETF, Cairo.

Hair, J. F. (2014). on Multivariate Data Analysis Joseph F. Hair Jr. William C. Black. 
Irani, S. (2011). Choosing what works. Industrial Engineer, IE, 43(8), 42-47. Jituri, S. Fleck, B.Ahmad, R. (2018) Lean or ERP- A decision Support System to Satisfy Business objectives. Procedia CIRP Vol (70) 422 $-427$

Kumar, S., Phillips, A., \& Rupp, J. (2009). Using six sigma DMAIC to design a high-quality summer lodge operation. Journal of Retail \& Leisure Property, 8(3), 173-191.

Lancaster, J. (2011) Lean and Six Sigma in Hospitality Organizations: Benefits, Challenges, and Implementation. University of Nevada, Las Vegas

Lee, S. M., Olson, D. L., Lee, S., Hwang, T., \& Shin, M. S. (2008). Entrepreneurial applications27 of the lean approach to service industries. Service Industries Journal, 28(7), 973-987.

Leite, H.d.R. \& Vieira, G.E. (2015). 'Lean Philosophy and its Applications in the Service Industry: A Review of the Current Knowledge', Production, 25(3), 529-541.

McMahon, T. (2014) A lean journey.

Accessible at http://www.aleanjourney.com (accessed 15/3/2019)

Melton T. (2005). The benefits of lean manufacturing what lean thinking has to offer the process industries. Chemical Engineering Research and Design, 83, 662-673.

Muijs, D. (2010). Doing quantitative research in education with SPSS. Sage.

Pande, P.S., Neuman, R.P. \& Cavanagh, R.R. (2002). The Six Sigma Way - An Implementation Guide for Process Improvement Teams. New York: Mcgraw-Hill.

Pearlman, D. M., \& Chacko, H. (2012). The quest for quality improvement: Using six sigma at Starwood Hotels and Resorts. International Journal of Hospitality \& Tourism Administration, 13(1), 48-66.

Phogat, S. (2013). An introduction to applicability of lean in shipbuilding. International Journal of Latest Research in Science and Technology, 2(6), 85-89.

Rauch, E., Damian, A., Holzner, P., \& Matt, D. T. (2016). Lean Hospitality-Application of Lean Management methods in the hotel sector. Procedia CIRP, 41, 614-619.

Rother, M., \& Shook, J. (2003). Learning to see: value stream mapping to add value and eliminate muda. Lean Enterprise Institute.

Simon, R. W., \& Canacari, E. G. (2012). A practical guide to applying lean tools and management principles to health care improvement projects. AORN journal, 95(1), 85-103.

Womack, P.J., Jones, D.T. Lean Thinking. Banish Waste and Create Wealth in Your Corporation. New York: Free Press; 2003. 